\title{
Presise epikriser
}

Epikrisens innhold og disposisjon er viktigere enn språklig perfeksjonisme. I en hektisk hverdag skal vi prioritere å gjøre epikrisen innholdsmessig meningsfull og ryddig fremfor å gjøre den språklig optimal. Likevel er det kanskje en sammenheng mellom slurvet språk og slurvet tanke?

Før var problemet ofte at epikrisene var svært korte og overfladiske: «Inn. Op. App. Ut.» Nå er problemet heller at de eser ut og blir veldig lange, men ikke alltid med så informativt innhold. Den som har ambisjoner om språklig stringens, kan forsøke å unngå noen fallgruver som epikriseskrivere ofte faller $i$.

\section{Bruk av «jeg» og presens}

Et pussig utslag av at epikriser nå i stor grad lages ved å «klippe og lime» er merkelig bruk av personlige pronomen og verbets tider. I innkomstjournalen står det kanskje: «I går kveld kjente pasienten seg mer tungpusten enn vanlig. Da hun våknet i dag tidlig var det blitt enda verre. ... Jeg vurderer dette som en hjertesviktforverring.»)

Det er greit i innkomstjournalen, men ugreit hvis det klippes uredigert inn i epikrisen. Det skaper forvirring om når noe faktisk skjedde, og hvem som har gjort hva. I beste fall er det bare språklig klønete. Det handler imidlertid ikke bare om språk og stil. Slike formuleringer kan også skape grunnlag for alvorlige misforståelser. Legen som skriver epikrisen er ansvarlig for det han eller hun skriver. Man kan gjerne gjøre andres ord til sine, men man må likevel redigere dem så det blir korrekt.

Ved å bruke det ubestemte pronomenet «man» i epikrisen, skapes det ofte uklarhet om hvem det er snakk om, for eksempel: «Man kan vurdere å utrede pasienten for kols.» Hvem er man? Fastlegen? Epikriseskriveren? «Man» lyder dessuten veldig oppstyltet og byråkratisk. Rådet er derfor: Unngå å bruke «man» i epikrisen.

\section{Tomgangsspråk}

Språk på tomgang ser vi typisk i dikterte epikriser. Det er et utslag av at den som dikterer, «småsludrer» med mikrofonen og sier ting som har liten informasjonsverdi eller er helt selvfølgelig: «Det dreier seg således om en 81 år gammel mann med problematikk knyttet til falltendens». Det kan enkelt erstattes av «81 år gammel mann med falltendens».

Andre eksempler på selvfølgeligheter som vanligvis like gjerne kan droppes, er: «Man undersøker pasienten på visitten», «Pasienten har fått behandling og rehabilitering av avdelingens tverrfaglige team»,

«Pasienten bor i et hus» og «Pasienten sitter $i$ en stol».

\section{Jålebegreper}

Det er masse merkelig slang i helsevesenet som ikke har noen annen funksjon enn

Tabell 1 Jålebegreper og forslag til bedre alternativer

\begin{tabular}{|c|c|}
\hline Ikke skriv & Skriv heller \\
\hline Falt $\times$ fler & Falt flere ganger \\
\hline Hospitalisert & Innlagt \\
\hline Multimorbid & $\begin{array}{l}\text { Har mange sykdommer (men som regel er det helt unødvendig } \\
\text { å skrive det i epikrisen i det hele tatt - epikrisen omtaler jo alle } \\
\text { disse sykdommene, og da kan leseren se helt av seg selv at det } \\
\text { er mange av dem) }\end{array}$ \\
\hline Fatigue & Utmattelse \\
\hline Cerebralt insult, apopleksi & Hjerneslag - eller helst hjerneinfarkt, hjerneblødning \\
\hline Problematikk & Problem \\
\hline Tilbakemelding & Svar \\
\hline Metodikk & Metode \\
\hline Størrelsesorden & Størrelse \\
\hline Man & Vi, jeg, fastlegen, sykehjemslegen \\
\hline $\begin{array}{l}\text { Rimelig allmenntilstand, } \\
\text { rimelig klar og orientert }\end{array}$ & $\begin{array}{l}\text { Beskriv mer presist om du vurderer allmenntilstanden som god, } \\
\text { lett redusert eller sterkt redusert, og hvorvidt pasienten er orien- } \\
\text { tert eller ikke }\end{array}$ \\
\hline Per nå & $\begin{array}{l}\text { Nå, i dag (men som regel helt overflødig, fremgår av sammen- } \\
\text { hengen) }\end{array}$ \\
\hline I forhold til & $\begin{array}{l}\text { Når det gjelder, med hensyn til («i forhold til» betyr «sammen- } \\
\text { lignet med», og kan brukes når det er det du vil si) }\end{array}$ \\
\hline
\end{tabular}

Tabell 2 Vanlige særskrivingsfeil i medisinske journaler

\section{Det heter ikke}

Influensa prøver

Luftveis symptomer

Penicillin behandling

Lunge kreft

Venstre forskyvning

Ankel brudd å skape avstand og gi det vi sier og skriver, et litt mystisk preg. Med dette mener jeg ikke genuin medisinsk terminologi, der en fagterm kan være både mer presis og mer dekkende enn et norsk hverdagsord. I slike tilfeller er det ikke bare tillatt, men anbefalt, 
at vi bruker det presise medisinske fagordet i epikrisen.

Med «jålebegreper» mener jeg ord som ikke øker presisjonsnivået, men som vesentlig brukes blant helsearbeidere og ikke blant folk flest. I tabell 1 har jeg samlet noen eksempler (tab 1).

\section{Særskriving}

Hovedregelen i norsk er at sammensatte ord skrives som ett ord (samskriving). Bruk av feilaktig oppdeling av ordene (særskriving) griper om seg, ikke minst i journal- og epikrisetekster. Dette drives bl.a. frem av at særskriving er vanlig i engelsk (det heter «blood test» på engelsk og «blodprøve» på norsk), og av at retteprogrammer og programmer for talegjenkjenning oftere kjenner igjen de to enkeltordene separat enn det sammensatte ordet ( tab 2).

\section{Torgeir Bruun Wyller}

t.b.wyller@medisin.uio.no

Torgeir Bruun Wyller (f. 1960) er spesialist i indremedisin og i geriatri, professor i geriatri ved Universitetet i Oslo og overlege ved Geriatrisk avdeling, Oslo universitetssykehus.

Redaktør: Erlend Hem. 